\title{
George Revell: Conservationist and Game Guardian
}

by R. D. Symons, Regina

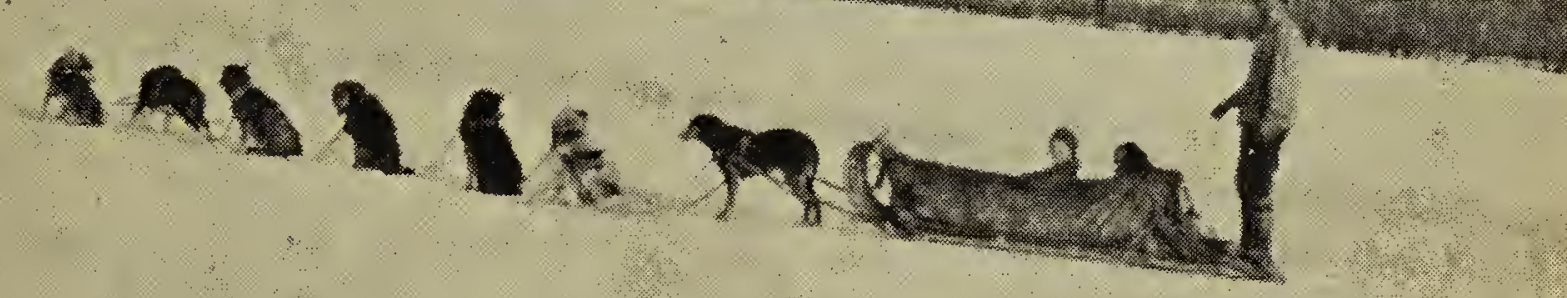

G. Revell with dog train, Primrose Lake

From the Pas, Manitoba to Cold Lake, Alberta, few men were held in higher esteem and respect than George Revell, one of the early game officers of Saskatchewan.

George Revell was born at Newton Abbot, Devonshire, in 1888. He came at an early age to Manitcba. In 1917 he joined the :R.N.W.M.P. and was sent to " $E$ " Division at Prince Albert. Later, because of his life-long interest in wildlife, he wanted to associate himself with conservation and the protection of cur resources. In 1920 , on the recommendation of Superintendent Rutledge, Officer Commanding at Prince Albert, Revell was gazetted as Provincial Game Guardian, under the late Fred Bradshaw, the Game Commissioner.

Revell, and others like him, became game guardians because they were convinced of the importance of their work, because of the contribution it could make to conservation. As Bradshaw used to say when he sent his game guardians out: "It's not just a jcb, it's an cpportunity."

Revell was sent to patrol an enormous country from the Manitoba border to Prince Albert and indefinitely north. He travelled thousands of miles in the bush, camping when cvertaken by night. He travelled on snowshoes with a back-pack, or by dog-train, saddle horse or team. canoes and boats, gas "jigger" on the Hudson Bay Railway, and when occasion demanded, the caboose of a freight train with his faithful dogs curled up in an empty box car. The train crews were co-operative and thoughtful, and the engineer was always willing to stop the train for Revell to unload and head into the bush.

In 1932 , with the formation of the Department of Natural Resources, Revell was retained to become a Field Officer, Land Inspector and Forest Ranger. At that time he was sent to Cold Lake to clean up the Alberta border. His patrols took him to Primrose Lake and Ile à la Crosse, as well as to the Beaver River-Meadow LakeGreen Lake area. In 1937 he took over the Battleford district and later was sent to Strasbourg where he was staticned until 1945.

Far from roads, with no communications, with transportation limited to dogs, horses or foot travel, spending days and often weeks in a wilderness country, subject to all the hazards of weather, swollen streams and shortage of food, Revell was left $\mathrm{cn}$ his own to make successful investigations and arrests in the face of (nearly always) superior numbers of armed and cften dangerous men. Is it any wonder that Superintendent Rutledge said of Revell and of game 


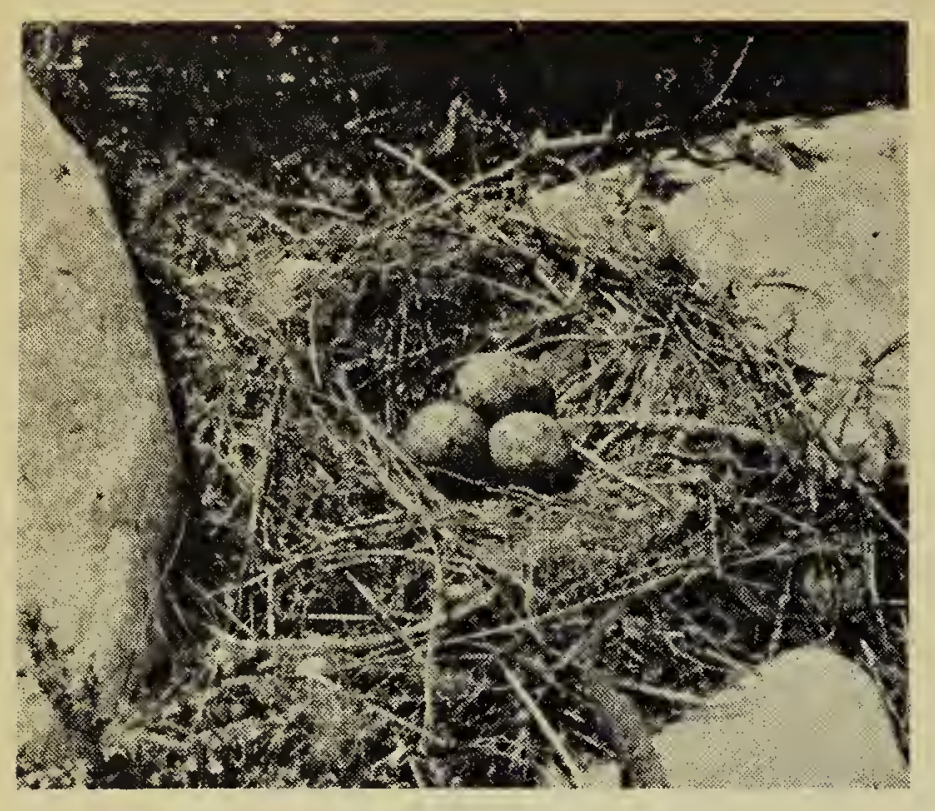

Photo by G. Revell Nest of Ring-billed Gull, Last Mountain Lake

guardians in general, they "literally carried their lives in their hands, by night and by day, year after year'?

What was Revell's reward? The sum of $\$ 120.00$ per month, reduced in the years of the great drcught to $\$ 75.00$ per month. But no one grumbled, for men such as this had sworn to do their duty withcut fear or favour. Revell never broke that cath, and as he faithfully discharged his duties of law enforcement, he helped to establish the idea of protecting wild animals from selfish or irresponsible hunting. In districts which he patrolled a respect for conservation was thus imposed.

Many tales could be told of the suffering and danger of Revell's long patrols. I shall tell of two of these incidents, briefly.

On one occasicn-in winter-Revell was on routine patrol by team and sleigh. Following suspicious tracks he came to a new winter camp snuggled in the heavy spruce near the Middle Muskeg River. Six illegal fur trappers, armed and hostile, were in possession. Revell disarmed them, emptied : their rifles and seized all ammunition. Still keeping control over them, he seized illegal furs to the value of $\$ 3,000$ which he packed in his sleigh. .He then ordered them to march ahead of his team, each carrying his empty rifle as an impediment, over the long and weary miles to Meadow Lake where they were tried and convicted.

On his return to his cabin at Pierce Lake he bundled the furs into a treecache, for he was off again on another "job" and could not then take time to send them to Regina. During his absence Mrs. Revell stood guard over this government property with a loaded shotgun.

On another occasion he disappeared for a week into the wild bush towards Primrose Lake. Mr. Barns, at Barns' Crossing on the Beaver said, "I saw George 'coming in' a week later (on foot) herding five men ahead of him. I said to him, "What have ycu got, George - the Russian Army'?" Revell had found these Alberta fur thieves "shacked up" and had taken appropriate action. From Barns he got a team and sleigh to convey the prisoners to Meadow Lake.

These typical incidents in the life of a game guardian show us the sense of dedication which upheld George Revell. Where such men enforced the Game Act, the poacher was bold indeed who attempted to ply his trade, and the game-hog soon became convinced that he must abide by the law or take the consequences. In the annals of game and wildlife ccnservation the name of Revell stands out as an inspiration.

George Revell lives, quietly and simply tcday in our city of Regina.

\section{THE NENE GOOSE OF HAWAII}

A watercolour drawing of a pair of Nene Geese (see back ccver) on the volcanic slopes of Hawaii will be the 1964-65 Migratory Bird Hunting Stamp. Each waterfowl hunter in the United States is required to purchase this \$3 "duck stamp" in addition to his regular state hunting license. The revenue is used for the development of migratory bird refuges and habitat.

The 87 artists who entered the 15 th annual "duck stamp" contest had been urged to show species of waterfowl not appearing on the 30 previous issues of stamp. The prize winning design, showing a fully protected species which may not be hunted anywhere, was drawn by Stanley Stearns of Stevensville, Maryland.

The Nene Gcose (pronounced "naynay'), one of the rarest of all waterfowl, is seriously threatened with extinction. The birds are native only in the Hawaiian Islands and in the wild they live cnly at elevations of between 5,000 and 8,000 feet. Their feet, now, are only partly webbed. 